RHODORA, Vol. 111, No. 945, pp. 1-20, 2009

(c) Copyright 2009 by the New England Botanical Club

\title{
BRYOPHYTES OF ADJACENT SERPENTINE AND GRANITE OUTCROPS ON THE DEER ISLES, MAINE, U.S.A.
}

\author{
LAura R. E. Briscoe
}

The Field Museum, 1400 South Lakeshore Drive, Chicago, IL 60605

\section{TANNER B. HARRIS}

University of Massachusetts, Fernald Hall, 270 Stockbridge Road, Amherst, MA 01003

\section{WiLLIAM BRousSARD}

University of Maine, 421 Estabrooke Hall, Orono, ME 04469

\author{
Eva Dannenberg, Fred C. Olday, and Nishanta Rajakaruna ${ }^{1}$ \\ College of the Atlantic, 105 Eden Street, Bar Harbor, ME 04609 \\ ${ }^{1}$ Author for Correspondence; Current Address: Department of Biological \\ Sciences, One Washington Square, San José State University, \\ San José, CA 95192-0100 \\ e-mail: nishanta.rajakaruna@sjsu.edu
}

\begin{abstract}
The serpentine-substrate effect is well documented for vascular plants, but the literature for bryophytes is limited. The majority of literature on bryophytes in extreme geoedaphic habitats focuses on the use of species as bioindicators of industrial pollution. Few attempts have been made to characterize bryophyte floras on serpentine soils derived from peridotite and other ultramafic rocks. This paper compares the bryophyte floras of both a peridotite and a granite outcrop from the Deer Isles, Hancock County, Maine, and examines tissue elemental concentrations for select species from both sites. Fifty-five species were found, 43 on serpentine, 26 on granite. Fourteen species were shared in common. Twelve species are reported for the first time from serpentine soils. Tissue analyses indicated significantly higher $\mathrm{Mg}, \mathrm{Ni}$, and $\mathrm{Cr}$ concentrations and significantly lower $\mathrm{Ca}: \mathrm{Mg}$ ratios for serpentine mosses compared to those from granite. Soil analyses demonstrated significant differences between the two substrates.
\end{abstract}

Key Words: bryophytes, substrate ecology, edaphic factor, heavy metal tolerance, serpentine, ultramafic ecology

Although climate plays a fundamental role in determining species ranges, within climatic regions the edaphic factor (Mason 1946a, b; Rajakaruna and Boyd 2008) plays a critical role in the distribution patterns displayed by plant species (Jenny 1941; Kruckeberg 2002). 
Due to the extreme edaphic conditions presented by serpentine soils, these substrates have received much attention from botanists worldwide (Baker et al. 1992; Boyd et al. 2004). Serpentine soils are weathered from peridotite and other ultramafic rocks containing more than $70 \%$ ferromagnesian silicate (mafic) minerals (Kruckeberg 1984). They are often high in heavy metals such as $\mathrm{Ni}$ and $\mathrm{Cr}$ and low in $\mathrm{Ca}$ with $\mathrm{Ca}: \mathrm{Mg}$ ratios $<1$, unfavorable conditions for plant growth (Brady et al. 2005).

The serpentine syndrome (Jenny 1980) - the overall effect of serpentine soils on plant species - is a worldwide phenomenon characterized by high rates of endemism, disjunct distributions, and ecotypic differentiation among vascular plants (Brooks 1987). Serpentine soils often act as stimuli for speciation events (Rajakaruna 2004) and provide model settings in which to study the processes of plant divergence. Serpentine floras have been studied extensively in western North America, Europe, Cuba, New Caledonia, and parts of Africa and southeastern Asia (Brooks 1987; Kruckeberg 2002; Roberts and Proctor 1992). However, literature from eastern North America is limited (Rajakaruna et al. 2009).

Despite numerous studies on the serpentine substrate effect for vascular plants (Alexander et al. 2007; Brooks 1987), bryophytes have received minimal attention. However, from the few published reports available it is clear that much of what is known about the effects of serpentine on vascular plants also applies to bryophytes (Sigal 1975), although species-level endemism is not a common phenomenon among this group of plants (Alexander et al. 2007; Lepp 2001; Sigal 1975). In comparison to vascular plants, bryophytes exhibit low levels of endemism and ecotypic formation in response to serpentine and other extreme substrates (Shaw et al. 1987). The only proposed serpentine endemic moss is Pseudoleskeella serpentinensis, reported from California (Shevock 2003). Sigal (1975) listed 31 moss species and five liverwort species from serpentine outcrops in California. In Cuba, well known for its high rates of serpentine endemism among vascular plants (Boyd et al. 2004), Marín et al. (2004) found $61 \%$ of the island's bryophytes (of a total 195 genera, 582 species) occurred on serpentine, although none were restricted to the substrate (Borhidi and Pócs 1985). Sirois (1984) listed 82 moss species and 33 liverwort species from serpentine substrates on Mt. Albert, Gaspésian Provincial Park, Québec. In a comparative study in British Columbia, Lewis et al. (2004) found bryophyte richness and abundance to be lower on 
serpentine soils (43 species) than adjacent non-serpentine soils (50 species). The authors suggested that community patterns there were more strongly influenced by microclimate than soil type.

The current study provides a checklist of bryophytes from two abandoned quarries - one serpentine and one granite - with similar ecological features and land-use histories found in close proximity in the Deer Isle complex in coastal Maine. Species composition is compared between sites and with results from similar comparative studies of bryophytes on edaphically challenging substrates. Finally, soil characteristics and tissue analyses for selected species are presented for each site.

\section{MATERIALS AND METHODS}

Bryophytes were collected between November 2006 and January 2007 from Pine Hill and Settlement Quarry on Little Deer Isle and Deer Isle (respectively), Hancock County, Maine, U.S.A. Pine Hill is a former peridotite (herein referred to as serpentine) quarry on Little Deer Isle $\left(44^{\circ} 17^{\prime} 07.3^{\prime \prime} \mathrm{N}, 68^{\circ} 42^{\prime} 06.7^{\prime \prime} \mathrm{W}\right.$, WGS 84). The site is approximately $0.16 \mathrm{~km}^{2}$, located approximately $0.8 \mathrm{~km}$ inland from Penobscot Bay. See Harris et al. (2007) for a detailed description of the site and history of quarry activities. At Pine Hill, only bryophytes growing directly on serpentine substrates were collected. Plants were collected from as many microhabitats as possible, the site's small size making it possible to survey nearly the entire site.

Settlement Quarry is a former granite quarry on adjacent Deer Isle $\left(44^{\circ} 10^{\prime} 37.6^{\prime \prime} \mathrm{N}, 68^{\circ} 38^{\prime} 20.7^{\prime \prime} \mathrm{W}\right.$, WGS 84), otherwise having aspects, altitude, and climate similar to Pine Hill. The area of the quarry is approximately 4-5 times greater than the area of Pine Hill, although the outcrop itself is located a similar distance inland from Penobscot Bay. The quarry was most active in the 1920s and subjected to bouts of quarrying throughout the middle part of the century, with activity ceasing permanently in 1980. The texture and composition of the quarry rock is remarkably even throughout the outcrop, with the main mass of the granite consisting of the minerals microcline and plagioclase feldspar, quartz, and biotite (Stewart and Tucker 1998). The vegetation on the outcrop is characteristic of plant communities found on granite and other non-mafic substrates elsewhere in the region. The floor of the quarry is mostly barren, but supports mosses, lichens, grasses, and large mats of Sibbaldiopsis tridentata (Rosaceae). Various shrubs 
and small trees occur in soil pockets located adjacent to rock walls and fractures, primarily Alnus incana subsp. rugosa (Betulaceae), Comptonia peregrina (Myricaceae), Picea glauca (Pinaceae), Prunus virginiana (Rosaceae), and Vaccinium angustifolium (Ericaceae). Various herbaceous plants occur on areas where soil has accumulated, primarily Fragaria virginiana (Rosaceae), Trientalis borealis (Primulaceae), Viola sagittata (Violaceae), and a number of graminoids. Surrounding the quarried area is a dense spruce-fir forest with few vascular plants in the understory, interspersed with stands of Betula papyrifera (Betulaceae).

Collections at Settlement Quarry were made from as many microhabitats as possible to ensure diverse and comprehensive sampling. As with Pine Hill, the small size of Settlement Quarry allowed us to survey a majority of the site. Specimens from both sites were identified using Crum (1991), Ireland (1982), and Ireland and Bellolio-Trucco (1987). A complete set of voucher specimens was deposited in the College of the Atlantic herbarium (HCOA), with selected specimens deposited at the Missouri Botanical Garden (MO) and the New York State Museum (NYS).

A subgroup of species from each site was chosen for tissue elemental analyses. Due to the small size of moss populations at both sites, it was only possible to sample two species held in common between the two sites - other species sampled were unique to each site. At Pine Hill, collections were made of Ceratodon purpureus, Dicranum scoparium, Hypnum cupressiforme, Polytrichum juniperinum, P. piliferum, Ulota hutchinsiae, and Weissia controversa. For each species, collections were made from at least two separate populations, except for $D$. scoparium whose populations were too small to justify multiple collections. At Settlement Quarry, multiple collections were made of Dicranum spurium, $P$. juniperinum, $P$. piliferum, and Pohlia nutans. Due to the small amounts of tissue available, collections from each site were pooled by species prior to preparation for tissue analysis.

Each collected sample was shaken to remove loosely adhering soil and organic matter and then thoroughly rinsed in the field with $100 \mathrm{ml}$ distilled water and packaged with paper towels. Rhizoids and the lower portion of each stem were removed in the laboratory using a razor blade. Each sample was then stirred in $100 \mathrm{ml}$ distilled water for one minute at medium speed using a standard magnetic stirrer, strained with a small sieve, and stirred again at medium speed in $100 \mathrm{ml}$ distilled water for an additional minute. Samples 
were strained, air dried for three days in paper towels, then dried at $110^{\circ} \mathrm{C}$ in a forced draft oven for 48 hours. Dried samples were placed in a desiccation chamber for approximately 24 hours before being ground to a fine powder in a mortar with liquid nitrogen.

Tissue elemental analyses were conducted by the dry ashing method using inductively coupled plasmaspectroscopy (ICP) at the Analytical Laboratory of the University of Maine at Orono. Tissue samples were analyzed for total $\mathrm{Ca}, \mathrm{Mg}, \mathrm{Na}, \mathrm{K}, \mathrm{P}, \mathrm{B}, \mathrm{Cu}, \mathrm{Fe}, \mathrm{Mn}$, $\mathrm{Zn}, \mathrm{Cr}$, and $\mathrm{Ni}$ concentrations.

Soil samples were collected at random from Pine Hill $(\mathrm{n}=18)$ and Settlement Quarry $(n=15)$. Samples were collected from the surface to $5 \mathrm{~cm}$ depth from areas where bryophytes were collected for tissue analyses. Collections were made with a plastic hand trowel. Samples were air dried in the laboratory for one week and stored in plastic bags. Analyses were carried out on the $2 \mathrm{~mm}$ fraction obtained using a brass sieve. Values for $\mathrm{pH}$ were obtained following Kalra and Maynard (1991) using the 1:2 soil-to-solution method with $\mathrm{H}_{2} \mathrm{O}$ and $0.01 \mathrm{M} \mathrm{CaCl}_{2}$.

Metal, cation, and cation exchange capacity (CEC) analyses were also conducted by the University of Maine Analytical Laboratory. Soils were analyzed for $\mathrm{Cr}, \mathrm{Fe}, \mathrm{Ni}, \mathrm{Mn}, \mathrm{Cu}$, and $\mathrm{Zn}$ concentrations by extraction with $0.005 \mathrm{M}$ diethylene-triamine-pentaacetic acid (DTPA) buffered with triethanolamine to $\mathrm{pH} 7.3$ (Lindsay and Norvell 1978) and subsequent detection by inductively coupled plasma optical emission spectrometry (ICP-OES) using matrixmatched calibration standards. Soils were analyzed for $\mathrm{Ca}, \mathrm{K}, \mathrm{Mg}$, $\mathrm{Na}$, and CEC by extraction with neutral ammonium acetate and concentrations determined by ICP-OES.

\section{RESULTS}

Table 1 lists 43 bryophyte species collected from Pine Hill and 26 from Settlement Quarry. Fourteen species were held in common between the two sites. Twelve species of liverworts (Marchantiophyta) were found at Pine Hill while half that number (6) were found at Settlement Quarry. Pine Hill harbored 31 species of mosses (Bryophyta) while Settlement Quarry harbored 20 species. Of the 43 species listed for Pine Hill, 12 are new reports for serpentine and other metal-enriched soils worldwide (Bates 1978; Belland and Brassard 1988; Brassard 1975; Hechavarria et al. 2004; Lewis et al. 2004; Marín et al. 2004; Samecka-Cymerman et al. 


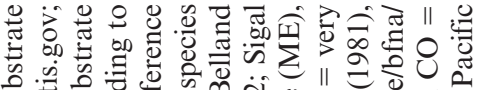

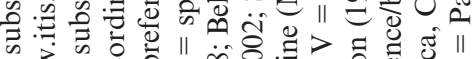

б $\|$ ठ

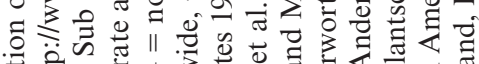

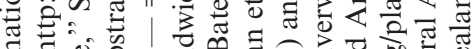

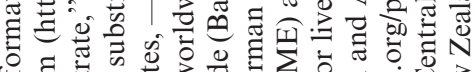

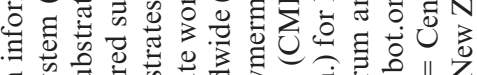

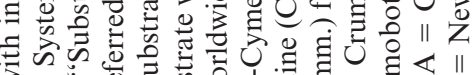

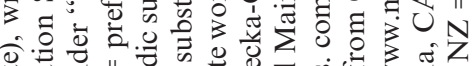
बิ

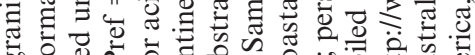

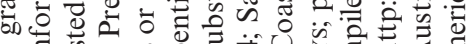

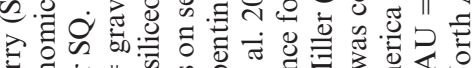

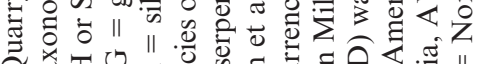

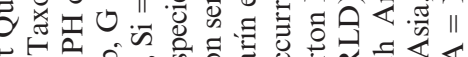

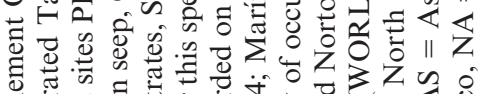

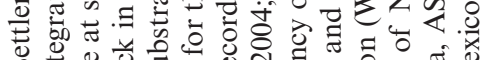

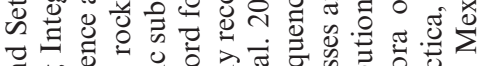

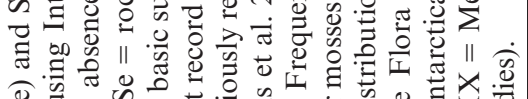

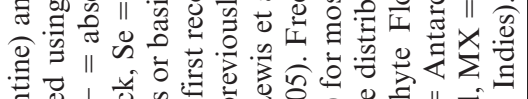
预 |

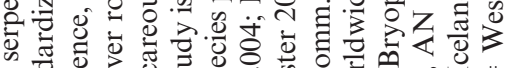

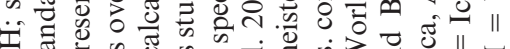

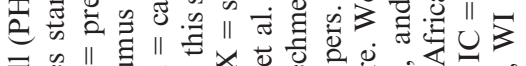
踏

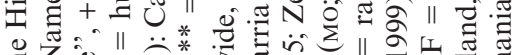

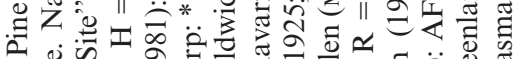
둔

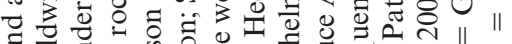

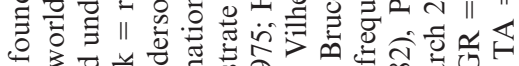

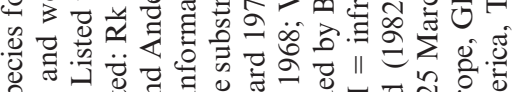
की क

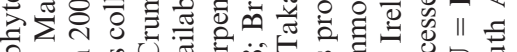

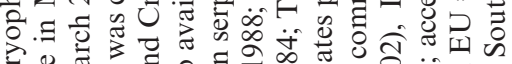
\& . .

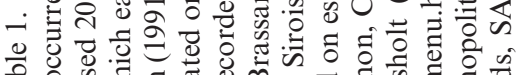

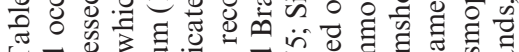

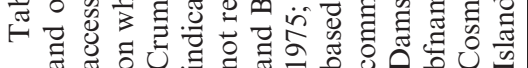

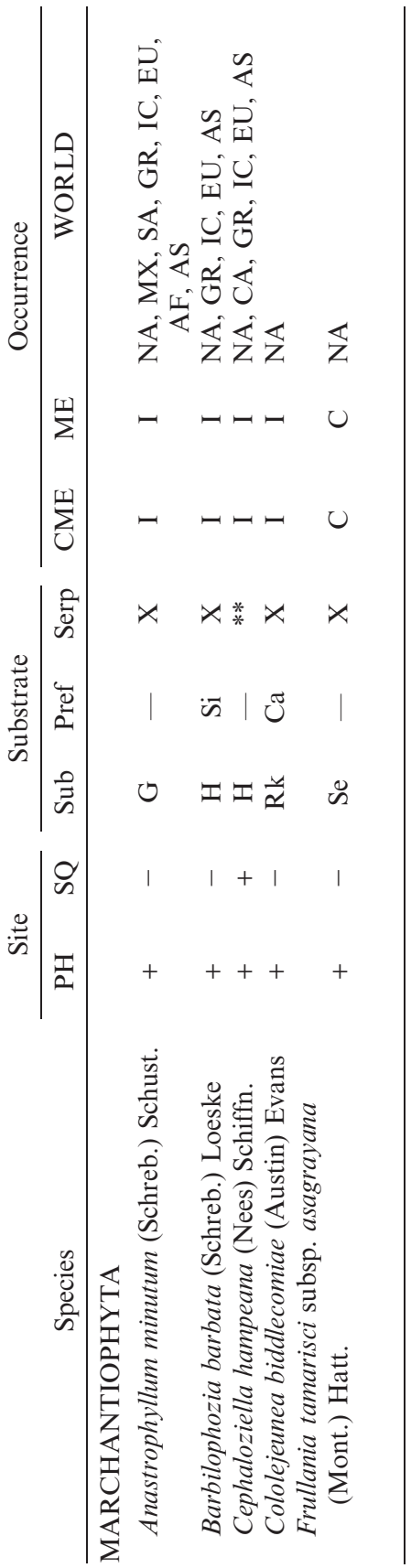




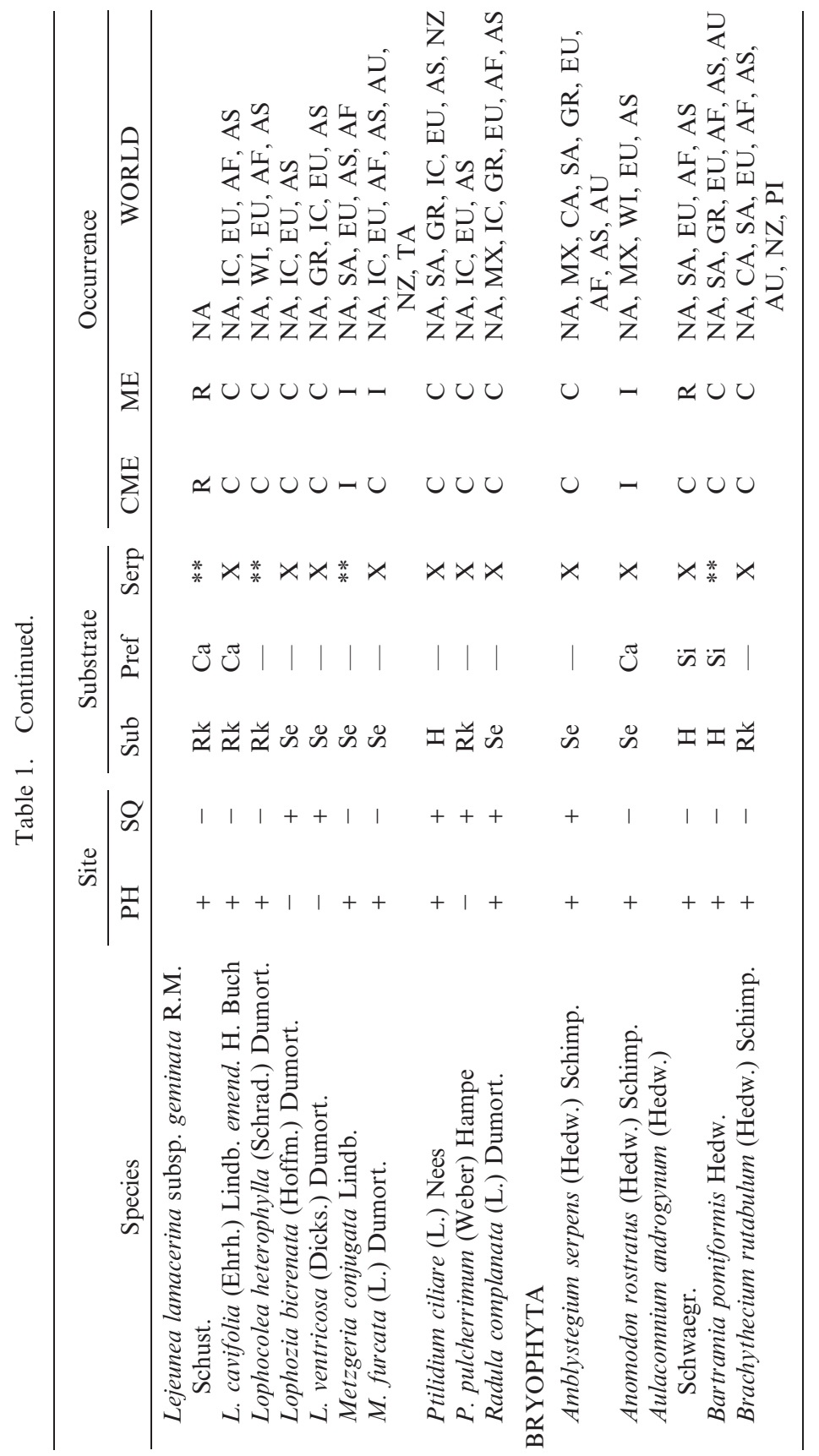




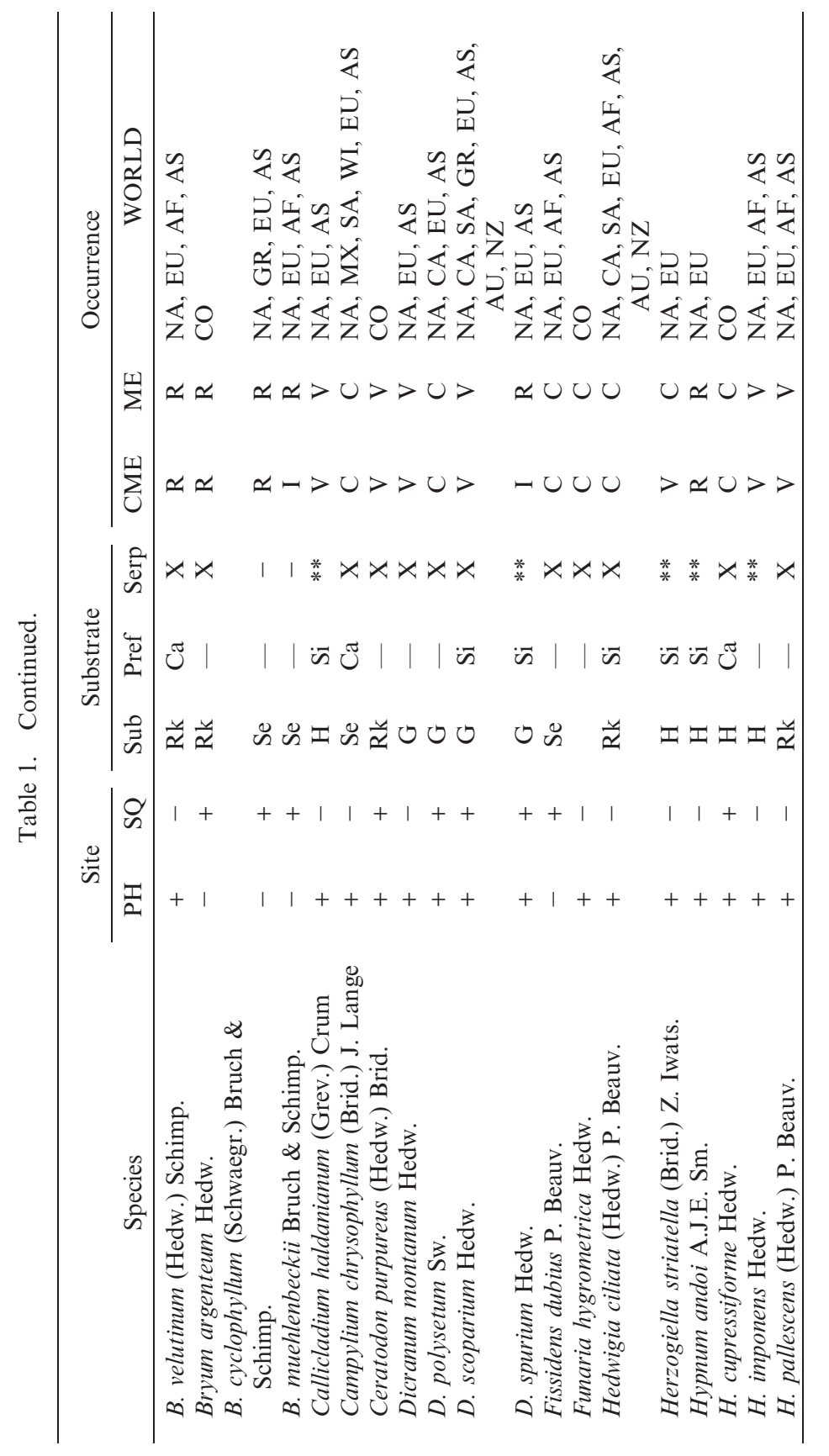




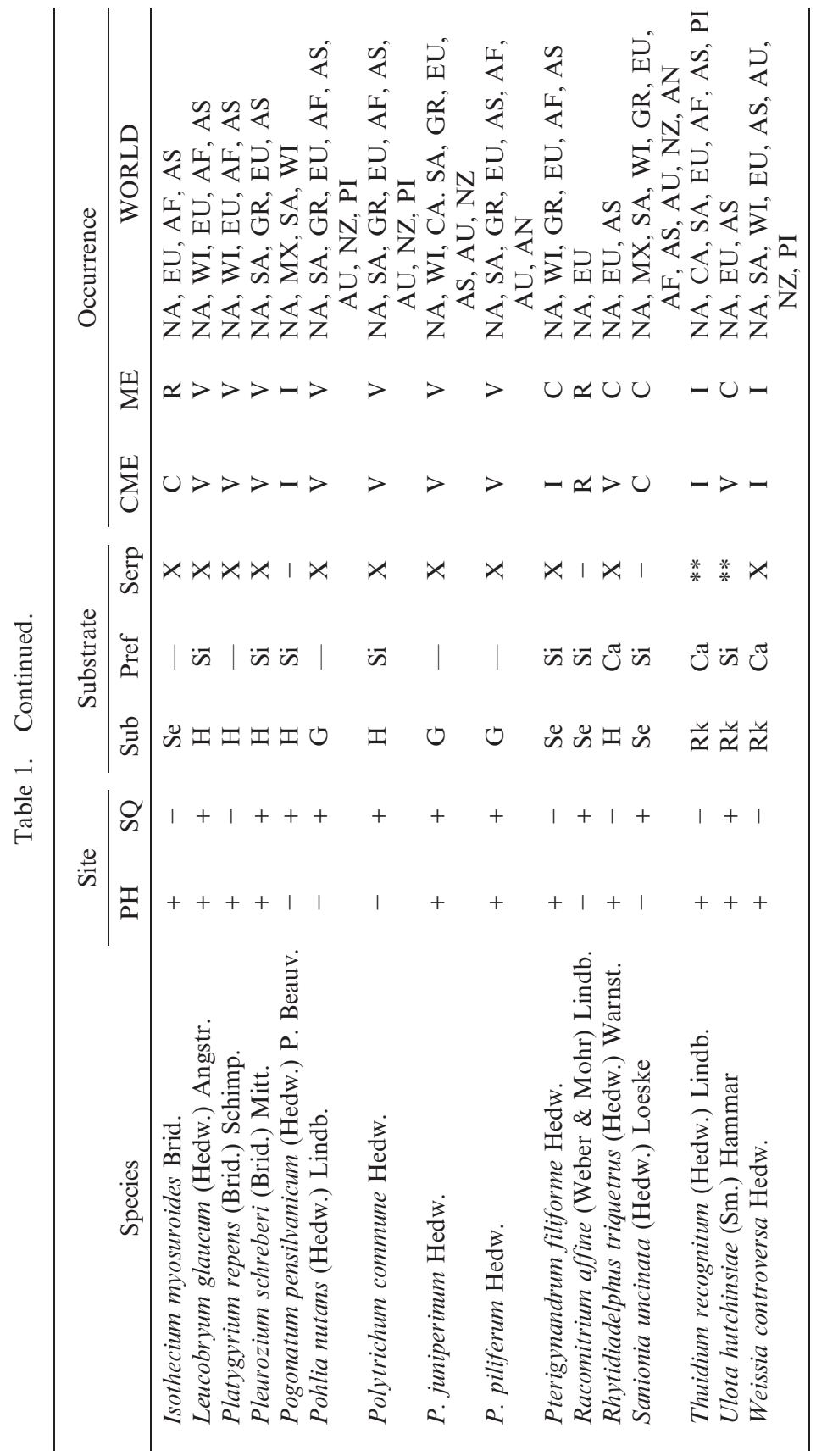


2002; Sigal 1975; Sirois 1984; Takaki 1968; Vilhelm 1925; Zechmeister 2005). For each of the species listed in Table 1, frequency of occurrence is indicated for Maine and coastal Maine (B. Allen, MO, pers. comm.; N. Miller, NYs, pers. comm.). Worldwide distribution is indicated according to Crum and Anderson (1981), Damsholt (2002), Ireland (1982), and Paton (1999). Many of the species collected are common in Maine; however, we documented several species either rare statewide or for coastal Maine (B. Allen and N. Miller, pers. comm.), both on serpentine (Aulacomnium androgynum, Brachythecium velutinum, Dicranum spurium, Hypnum andoi, Isothecium myosuroides, Lejeunea lamacerina subsp. geminata) and on granite (Bryum argenteum, B. cyclophyllum, B. muehlenbeckii, D. spurium, Racomitrium affine).

Results of tissue analyses for metal and cation concentrations are reported in Table 2. Species at Pine Hill showed consistently lower $\mathrm{Ca}: \mathrm{Mg}$ ratios and higher concentrations of heavy metals (Ni, Cr) than species collected from Settlement Quarry. At the community level, the seven serpentine taxa differed significantly (F-test) from the four taxa collected from granite in tissue $\mathrm{Mg}(P<0.0001), \mathrm{Ca}: \mathrm{Mg}(P<0.005)$, $\mathrm{Cr}(P<0.0001)$, and $\mathrm{Ni}(P<0.0001)$. Polytrichum juniperinum and $P$. piliferum were the only species shared by both sites to be included in the tissue analyses. Both taxa showed higher $\mathrm{Cr}$ and $\mathrm{Ni}$ concentrations on serpentine soils. However, while $P$. juniperinum managed to maintain a $\mathrm{Ca}: \mathrm{Mg}$ ratio $>1$ on both substrates, its congener, $P$. piliferum, showed a ratio $<1$ on serpentine and $>1$ on granite.

Soil analyses (Table 3) indicated that soil chemical features at Settlement Quarry were quite distinct from those at Pine Hill, with consistently lower heavy metal concentrations and significantly higher $\mathrm{Ca}: \mathrm{Mg}$ ratios characteristic of regional soils derived from granite and other non-ultramafic rocks. One-way ANOVA indicated that all 14 soil features tested were significantly different between the two sites.

\section{DISCUSSION}

Almost twice the number of species of bryophytes were found growing on serpentine than on granite. Over half the species found on granite were also found on serpentine. The latter category consisted of mostly ubiquitous species typical of exposed, sterile, acidic to basic sandy soils and rock outcrops (Crum 1991; Crum and Anderson 1981; Porley and Hodgetts 2005). This is not 


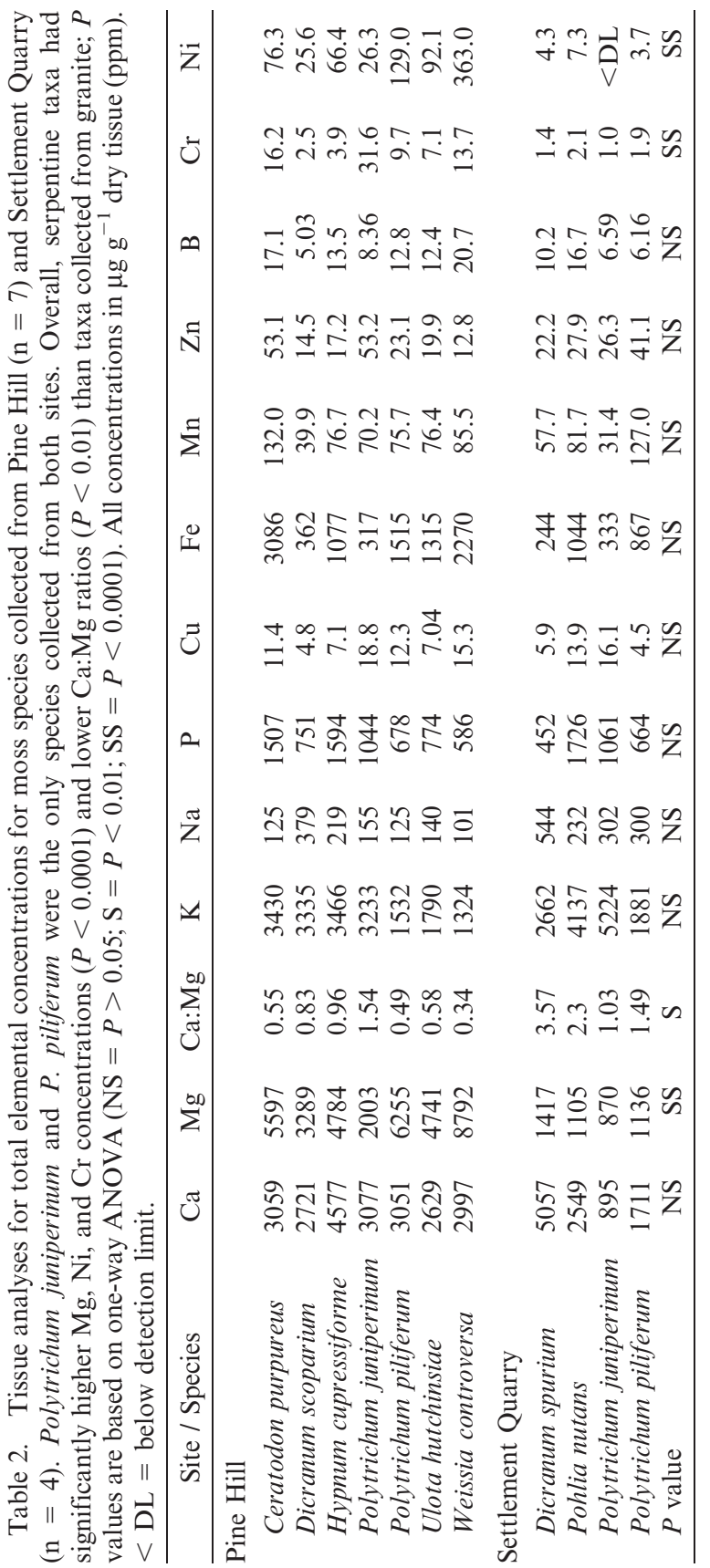


Table 3. Cation and heavy metal concentrations $\left(\mu \mathrm{g} \mathrm{g}^{-1}\right), \mathrm{pH}$ in water and $0.01 \mathrm{M} \mathrm{CaCl}_{2}$, and cation exchange capacity (CEC; meq $100 \mathrm{~g}^{-1}$ ) for soil samples from Pine Hill (serpentine; $\mathrm{n}=18$ ) and Settlement Quarry (granite; $\mathrm{n}=$ 15 ). Values listed are means \pm SE (range in parentheses) for samples collected $0-5 \mathrm{~cm}$ from soil surface in each outcrop. The significance in difference between the two sites was determined by one-way ANOVA.

\begin{tabular}{lccl}
\hline Soil Feature & Pine Hill & Settlement Quarry & $P$ Value \\
\hline $\mathrm{pH}: \mathrm{H}_{2} \mathrm{O}$ & $6.51 \pm 0.2(5.41-7.78)$ & $5.25 \pm 0.08(4.57-5.76)$ & $<0.001$ \\
$\mathrm{pH}: \mathrm{CaCl}_{2}$ & $5.81 \pm 0.2(4.81-7.13)$ & $4.24 \pm 0.11(3.54-5.02)$ & $<0.05$ \\
$\mathrm{CEC}$ & $14.76 \pm 1.7(3.6-27.5)$ & $1.72 \pm 0.25(0.53-4.69)$ & $<0.0001$ \\
$\mathrm{Cr}$ & $0.24 \pm 0.03(0.08-0.58)$ & $0.06 \pm 0.01(0.05-0.15)$ & $<0.0001$ \\
$\mathrm{Cu}$ & $3.78 \pm 0.3(2.1-7.3)$ & $1.97 \pm 0.5(0.15-7.2)$ & $<0.05$ \\
$\mathrm{Zn}$ & $7.08 \pm 1.8(0.45-31.5)$ & $2.3 \pm 1.3(0.05-20.4)$ & $<0.05$ \\
$\mathrm{Mn}$ & $31.23 \pm 10.7(3.1-90.8)$ & $2.32 \pm 0.7(0.35-9.50)$ & $<0.05$ \\
$\mathrm{Ni}$ & $44.84 \pm 5.6(12.1-101)$ & $0.13 \pm 0.02(0.05-20.4)$ & $<0.0001$ \\
$\mathrm{Fe}$ & $225.76 \pm 47.3(20.9-774)$ & $81.27 \pm 15.7(11.30-170)$ & $<0.05$ \\
$\mathrm{Na}$ & $27.02 \pm 3.4(10-69)$ & $10.82 \pm 1.2(7-25)$ & $<0.05$ \\
$\mathrm{~K}$ & $63.76 \pm 11.9(20-210)$ & $25.2 \pm 3.1(9-50)$ & $<0.05$ \\
$\mathrm{Ca}$ & $652.35 \pm 131.4(136-2035)$ & $86.32 \pm 16.02(30-246)$ & $<0.05$ \\
$\mathrm{Mg}$ & $1362.63 \pm 145.9(337-2319)$ & $20.6 \pm 3.5(7.1-49)$ & $<0.0001$ \\
$\mathrm{Ca}: \mathrm{Mg}$ & $0.45 \pm 0.05(0.22-1.03)$ & $4.34 \pm 0.4(2-8)$ & $<0.0001$ \\
\hline
\end{tabular}

surprising since many mosses are known to survive under a remarkable array of environmental stresses, enabling them to grow in a broad range of environments sometimes spanning several continents (Fernandez et al. 2006). Although none of the species found at Pine Hill are restricted to eastern North America, Pine Hill hosts a relatively diverse community compared to Settlement Quarry, a site with similar ecological characteristics and land-use history. Harris et al. (2007) reported a similar finding for lichens at Pine Hill, where a significantly higher number of saxicolous and terricolous species were found in relation to regional lichen floras from non-serpentine substrates. Downing (1992) reported similar patterns for bryophytes growing on limestone outcrops in eastern Australia. In contrast to these reports, Lewis et al. (2004) found lower bryophyte diversity on serpentine than on adjacent nonserpentine sites in British Columbia, Canada. Unfortunately, a lack of comparative studies for bryophytes found in edaphically challenging conditions makes it difficult to determine the relative importance of substrate versus other ecological factors in determining species distribution.

For vascular plants, edaphically challenging substrates such as serpentine outcrops, mine tailings, and limestone often support 
lower species numbers relative to adjacent sites with soils more favorable to plant growth (Whittaker 1954); however the vascular species found on such sites often show ecotypic differentiation or strict endemism (Kruckeberg 1984). Although studies on bryophytes do not show extensive ecotypic differentiation or edaphic endemism (Shaw 1991; Shaw and Albright 1990; Sigal 1975), lack of competition from other species, including more quickly growing vascular plants, may make such growth-limiting soils more suitable for colonization by slow-growing yet broadly tolerant mosses, making such sites generally more species rich than adjacent sites with soils more favorable for plant growth. Because mineral nutrition in pleurocarpous mosses is largely dependent on atmospheric deposition, it is tempting to suggest that they may have a selective advantage in serpentine-like habitats compared to acrocarpous mosses in which some uptake of metals from the soil seems to occur via rising capillary water (Tyler 1990). Our findings agree with this hypothesis, the Pine Hill site showing a higher percentage of pleurocarpous mosses $(58 \%)$ compared to Settlement Quarry (20\%). Many of the terricolous acrocarpous species present at Pine Hill are weedy moss species commonly known to colonize disturbed sites, including quarries and mine tailings (Jules and Shaw 1994; Porley and Hodgetts 2005). It is interesting to note that Bryum argenteum and Pohlia nutans, two widespread, weedy species with known occurrences on serpentine (Lewis et al. 2004; SameckaCymerman et al. 2002; Shaw and Albright 1990; Sirois 1984) were present at Settlement Quarry but not at Pine Hill. With their close proximity and similar ecological features and land-use histories, one might expect to find such widespread and apparently substrateindifferent species at both sites.

Several species known to prefer calcareous substrates were found at Pine Hill, including Anomodon rostratus, Brachythecium velutinum, Campylium chrysophyllum, Hypnum cupressiforme, Rhytidiadelphus triquetrus, Thuidium recognitum, and Weissia controversa (Crum and Anderson 1981; Porley and Hodgetts 2005). Surprisingly, however, none of the calcicole species listed for Newfoundland by Belland and Brassard (1988) were found at this site. A majority of the calcicole species at Pine Hill, $B$. velutinum, $C$. chrysophyllum, $H$. cupressiforme, $R$. triquetrus, and $W$. controversa, have also been reported from serpentine soils elsewhere (Bates 1978; Lewis et al. 2004; Sigal 1975; Sirois 1984; Takaki 1968). The calcifuge species Hedwigia ciliata, found at Pine Hill, has also been 
found on mafic substrates in Newfoundland (Belland and Brassard 1988) and ultramafic substrates elsewhere (Bates 1978; Sigal 1975). Harris et al. (2007) reported a similar cooccurrence of calcicolous and silicicolous lichen species at Pine Hill, a finding that has been reported for lichens from serpentine areas globally (Favero-Longo et al. 2004).

Weissia controversa is a common, weedy moss known from serpentine and other metal-contaminated soils worldwide (Shaw et al. 1987) and has been collected from serpentine in Cuba (Marín et al. 2004), Newfoundland (Brassard 1975), Québec (Sirois 1984), California (Sigal 1975), and Japan (Takaki 1968). A subspecies, $W$. controversa subsp. densifolia, is restricted to mine sites in Europe (Porley and Hodgetts 2005) and is extremely tolerant of metalliferous substrates. Interestingly, $W$. controversa is one of the more common mosses at Pine Hill, colonizing cracks and crevices along the outcrop walls, and along the top of the outcrop. Nickel concentrations in the tissues of this species were the highest (363 ppm) among all taxa examined.

Ceratodon purpureus, previously documented from serpentine areas around the world (Lewis et al. 2004; Samecka-Cymerman et al. 2002; Sirois 1984; Takaki 1968), appeared to be the most common species growing along the quarry floor of Pine Hill. Jules and Shaw (1994) demonstrated ecotypic differentiation among populations of this species in response to metal-contaminated soils surrounding a smelter in Pennsylvania, with populations growing in heavily contaminated soils near the smelter showing greater tolerance than those growing on more distant, moderately contaminated soils. A comparative study of populations of $C$. purpureus on and off serpentine might determine the extent of its tolerance to various components of the serpentine syndrome (Jenny 1980).

Hypnum cupressiforme, previously collected from serpentine areas worldwide (Bates 1978; Samecka-Cymerman et al. 2002; Takaki 1968), was one of the more abundant pleurocarps at Pine Hill. Because of its almost exclusive dependence on atmospheric deposition for mineral nutrition, as suggested by Rassmussen and Johnsen (1976), it has been successfully employed as a biomonitor for atmospheric deposition of a range of heavy metals (Sardans and Peñeulas 2005). Tissues samples from Pine Hill showed high concentrations of $\mathrm{Ni}$ and $\mathrm{Cr}$, and $\mathrm{Ca}: \mathrm{Mg}<1$, suggesting that tissue elemental concentrations in this species may be more heavily influenced by substrate than previously thought. However, as noted 
by Ward et al. (1977) in examining metal concentrations in populations of this species from mining areas in New Zealand, it is equally likely that such tissue concentrations are a result of minedust deposition.

Polytrichum juniperinum, previously recorded from serpentine sites on both coasts of Canada (Lewis et al. 2004; Sirois 1984), was one of two moss species present at both sites to be tested for tissue elemental concentrations. It is interesting to note that this species was able to maintain a $\mathrm{Ca}: \mathrm{Mg}$ ratio $>1$ even while growing on serpentine, suggesting an effective uptake mechanism for $\mathrm{Ca}$ or $\mathrm{Mg}$ exclusion from Ca-limited/Mg-rich soils (Brady et al. 2005; Rajakaruna et al. 2003). Both $\mathrm{Cr}$ and Ni concentrations in the Pine Hill populations of this species were significantly higher than those of Settlement Quarry, showing the highest $\mathrm{Cr}$ concentration $(31.6 \mathrm{ppm})$ for all species examined. The other moss tested from both sites, P. piliferum, previously recorded from serpentine in Poland (Samecka-Cymerman et al. 2002), showed a similar pattern with respect to $\mathrm{Cr}$ and $\mathrm{Ni}$; however, it failed to maintain a $\mathrm{Ca}: \mathrm{Mg}$ ratio $>1$ on serpentine soils. Additional sampling of both these species is warranted to determine the extent of physiological differentiation on and off serpentine.

Conspicuously absent from Pine Hill but present at Settlement Quarry was Pohlia nutans, a weedy species well documented from metal-enriched substrates worldwide (Tyler 1990). Species of the genera Pohlia and Bryum, found at Settlement Quarry but not Pine Hill, have been reported as pioneer mosses, frequently colonizing recently exposed post-glacial rock outcrops in many parts of the world (Kruckeberg 2002), including serpentine sites (Egger 1994; Lewis et al. 2004; Symecka-Cymerman et al. 2002; Shaw and Albright 1990). Shaw and Albright (1990) describe B. argenteum as an ecologically plastic, broadly tolerant species with surprisingly little genetic differentiation among populations arising from urban areas, serpentine outcrops, mine tailings, and industrial sites. Another moss conspicuously absent from Pine Hill was Racomitrium lanuginosum, abundant on the exposed serpentine of $\mathrm{Mt}$. Albert, Québec (Sirois and Grandtner 1992). In serpentinized areas of Newfoundland (Roberts 1992) and Britain (Johnston and Proctor 1977) this species accumulates high levels of $\mathrm{Ni}$ (up to $719 \mu \mathrm{g} \mathrm{g}^{-1}$ dry tissue). Extensive searches at Pine Hill failed to reveal this taxon.

Our preliminary comparison of species composition and tissue elemental analyses suggests that further studies are warranted to 
elucidate possible serpentine substrate-effects among bryophytes in eastern North America. Future work should be directed at determining morphological and physiological variation in species found both on and off serpentine. For example, morphological traits, including the number of gemmae per plant, leaf dimensions, and costa length are strongly influenced by substrate in some mosses (Shaw 1990). There is some evidence suggesting mosses on heavy metalenriched sites do not form sporophytes (Shaw and Albright 1990), and it is unclear if such a phenomenon exists for mosses found on and off serpentine soils. Experimental studies including reciprocal transplants and common garden studies may help distinguish serpentine-related factors from other ecological factors determining observed bryophyte distributions. Such studies may also reveal intraspecific variation in response to substrate and whether such variation is due to ecotypic differentiation or phenotypic plasticity. For instance, differences in growth rates and general vigor in response to substrate have been observed for several species found on and off metal-enriched sites (Shaw and Albright 1990).

As is the case for vascular plants and cryptogams alike, more outcrops in Maine, New England, and eastern North America in general should be surveyed to document species composition and community structure on and off serpentine (Rajakaruna et al. 2009). New species are likely to be discovered in such unusual edaphic settings as illustrated by the recent discovery of a moss (Orthotrichum kellmanii) restricted to sandstone outcrops in the central coast of California (Norris et al. 2004). Our 12 species previously unreported from serpentine soils represent a significant addition to the worldwide serpentine bryoflora. However, given that many bryophytes are broadly tolerant of edaphic conditions and widely distributed, our current understanding of species distribution on serpentine is likely a reflection of insufficient sampling efforts rather than actual occurrence.

Serpentine habitats are undergoing drastic changes due to everexpanding development, deforestation, mining, exotic species invasions, and atmospheric deposition of pollutants such as heavy metals or previously limited nutrients such as nitrogen (Rajakaruna and Boyd 2008; Williamson and Balkwill 2006). Such changes can have a significant impact on the biota of these unique habitats. Floristic surveys in support of conservation efforts should be encouraged to document the wealth of biological diversity being lost from such sites worldwide. This is particularly important in 
light of the genetic material such sites provide for biomonitoring (Markert et al. 2003) and bioremediation (Pilon-Smits 2005) of anthropogenic pollution.

ACKNOwLEDGMEnTS. This work was funded by a Maine Space Grant Consortium EPSCOR grant to N.R. and a Rothschild Faculty-Student Collaboration Grant to L.R.E.B., W.B., E.D., and N.R. from College of the Atlantic. The authors thank Bruce Allen of the Missouri Botanical Garden and Norton Miller of the New York State Museum for their generous assistance with identifications and for providing frequency estimates for Maine and Coastal Maine, and two anonymous reviewers for providing useful comments. We also thank Kathleen Tompkins, Jose Perez-Orozco, and Josie Rassat for assistance with soil analyses and in the preparation of the manuscript.

\section{LITERATURE CITED}

Alexander, E. B., R. G. Coleman, T. Keeler-Wolf, and S. P. Harrison. 2007. Serpentine Geoecology of Western North America. Geology, Soils, and Vegetation. Oxford Univ. Press, New York.

Baker, A. J. M., J. Proctor, and R. D. Reeves, eds. 1992. The Vegetation of Ultramafic (Serpentine) Soils. Intercept, Andover, Hampshire, U.K.

Bates, J. W. 1978. The influence of metal availability on the bryophyte and macrolichen vegetation of four rock types on Skye and Rhum. J. Ecol. 66: 457-482.

Belland, R. J. and G. R. Brassard. 1988. The bryophytes of Gros Morne National Park, Newfoundland, Canada: Ecology and phytogeography. Lindbergia 14: 97-118.

Borhidi, A. AND T. Pócs. 1985. Effects of serpentine on the distribution of cryptogams in Cuba. IAB Conference of Bryoecology, Budapest and Vácratót, 5-10 August 1985. Abstr. Bot. 9 (suppl.) 1: 10.

Boyd, R. S., A. J. M. BAKer, And J. Proctor, eds. 2004. Ultramafic rocks: Their soils, vegetation, and fauna. Proc. 4th International Conference on Serpentine Ecology. Science Reviews, St. Albans, Herts, U.K.

Brady, K. U., A. R. Kruckeberg, and H. D. Bradshaw JR. 2005. Evolutionary ecology of plant adaptation to serpentine soils. Annual Rev. Ecol. Evol. Syst. 36: 243-266.

Brassard, G. R. 1975. New or additional moss records from Newfoundland. Bryologist 78: 363-365.

Brooks, R. R. 1987. Serpentine and its Vegetation: A Multidisciplinary Approach. Dioscorides Press, Portland, OR.

Crum, H. A. 1991. Liverworts and Hornworts of Southern Michigan. Univ. Michigan Herbarium, Ann Arbor, MI. 
And L. E. Anderson. 1981. Mosses of Eastern North America. Columbia Univ. Press, New York.

Damsholt, K. 2002. The Illustrated Flora of Nordic Liverworts and Hornworts. Knud Gr@phic Consult, Odense, Denmark.

Downing, A. J. 1992. Distribution of bryophytes on limestones in eastern Australia. Bryologist 95: 5-14.

EGGER, B. 1994. Végétation et stations alpines sur serpentine près de Davos. Veröff. Geobot. Inst. ETH Stiftung Rübel Zürich 117: 1-275.

Favero-Longo, S. E., D. Isocrono, and R. Piervittori. 2004. Lichens and ultramafic rocks: A review. Lichenologist 36: 391-404.

Fernandez, J. R., J. R. Shevock, A. N. Glazer, and J. N. Thompson. 2006. Cryptic species within the cosmopolitan desiccation-tolerant moss Grimmia laevigata. Proc. Natl. Acad. Sci. U.S.A. 103: 637-642.

Harris, T. B., F. C. Oldday, and N. Rajakaruna. 2007. Lichens of Pine Hill, a peridotite outcrop in eastern North America. Rhodora 109: 430-447.

Hechavarria, M. E. P., A. M. Marín, and K. M. Martinez. 2004. Bryoflora of ultramafic areas of Pico Cristal National Park, Cuba, pp. 25-33. In: R. S. Boyd, A. J. M. Baker, and J. Proctor, eds., Ultramafic Rocks: Their Soils, Vegetation, and Fauna. Proc. 4th International Conference on Serpentine Ecology. Science Reviews, St. Albans, Herts, U.K.

Ireland, R. R. 1982. Moss Flora of the Maritime Provinces. National Museums of Canada, National Museum of Natural Sciences, Ottawa, ON, Canada. - AND G. Bellolio-Trucco. 1987. Illustrated Guide to Some Hornworts, Liverworts, and Mosses of Eastern Canada. National Museums of Canada, National Museum of Natural Sciences, Ottawa, ON, Canada.

Jenny, H. 1941. Factors of Soil Formation. McGraw-Hill, New York. 1980. The Soil Resource: Origin and Behavior. Springer-Verlag, New York.

Johnston, W. R. And J. Proctor. 1977. Metal concentrations in plants and soils from two British serpentine sites. Pl. \& Soil 46: 275-278.

Jules, E. L. And A. J. Shaw. 1994. Adaptation to metal-contaminated soils in populations of the moss Ceratodon purpureus: Vegetative growth and reproductive expression. Amer. J. Bot. 81: 791-797.

Kalra, Y. P. and D. G. Maynard. 1991. Methods Manual for Forest Soil and Plant Analysis. Information Report NOR-X-319, Forestry Canada, Northwest Region, Northern Forestry Centre, Edmonton, AB, Canada.

Kruckeberg, A. R. 1984. California Serpentines: Flora, Vegetation, Geology, Soils, and Management Problems. Univ. California Press, CA.

- 2002. Geology and Plant Life: The Effects of Landforms and Rock Type on Plants. Univ. Washington Press, Seattle, WA.

Lepp, N. W. 2001. Bryophytes and Pteridophytes, pp. 199-204. In: M. N. V. Prasad, ed., Metals in the Environment-Analysis by Biodiversity. Marcel Dekker, New York.

Lewis, G. J., J. M. Ingram, and G. E. Bradfield. 2004. Diversity and habitat relationships of bryophytes at an ultramafic site in southern British Columbia, Canada, pp. 199-204. In: R. S. Boyd, A. J. M. Baker, and J. Proctor, eds., Ultramafic Rocks: Their Soils, Vegetation, and Fauna. Proc. 4th International Conference on Serpentine Ecology. Science Reviews, St. Albans, Herts, U.K. 
Lindsay, W. L. AND W. A. Norvell. 1978. Development of a DTPA soil test for zinc, iron, manganese, and copper. J. Soil Sci. 42: 421-428.

Marín, A. M., K. Mustelier, M. Potrony, and A. Vicario. 2004. Charactizacion de la brioflora de las areas ultramafica Cubanas, pp. 19-23. In: R. S. Boyd, A. J. M. Baker, and J. Proctor, eds., Ultramafic Rocks: Their Soils, Vegetation, and Fauna. Proc. 4th International Conference on Serpentine Ecology. Science Reviews, St. Albans, Herts, U.K.

Markert, B. A., A. M. Breure, and H. G. Zechmeister. 2003. Bioindicators and Biomonitors: Principles, Concepts, and Applications. Elsevier Science Limited, Oxford, U.K.

Mason, H. A. 1946a. The edaphic factor in narrow endemism. I. The nature of environmental influences. Madroño 8: 209-226.

. 1946b. The edaphic factor in narrow endemism. II. The geographical occurrence of plants of highly restricted patterns of distribution. Madroño 8: $241-257$.

Norris, D. H., J. R. Shevock, And B. Goffinet. 2004. Orthotrichum kellmanii (Bryopsida, Orthotrichaceae), a remarkable new species from the central coast of California. Bryologist 107: 209-214.

Paton, J. A. 1999. The Liverwort Flora of the British Isles. Harley Books, Colchester, U.K.

Pilon-Smits, E. 2005. Phytoremediation. Annual Rev. Pl. Biol. 56: 15-39.

Porley, R. And N. G. Hodgetts. 2005. Mosses and Liverworts. Harper Collins, London, U.K.

Rajakaruna, N. 2004. The edaphic factor in the origin of species. Int. Geol. Rev. 46: 471-478. - AND R. S. Boyd. 2008. The edaphic factor, pp. 1201-1207. In: S. E. Jorgensen and B. Fath, eds., The Encyclopedia of Ecology, Vol. 2. Elsevier, Oxford, U.K.

, T. B. Harris, and E. B. Alexander. 2009. Serpentine geoecology of eastern North America: A review. Rhodora 111: 21-108.

M. Y. Siddiei, J. Whitton, B. A. Bohm, and A. D. M. Glass. 2003. Differential responses to $\mathrm{Na}^{+} / \mathrm{K}^{+}$and $\mathrm{Ca}^{2+} / \mathrm{Mg}^{2+}$ in two edaphic races of the Lasthenia californica complex (Asteraceae): A case for parallel evolution of physiological traits. New Phytol. 157: 93-103.

RASSMUSSEN, L. AND I. JOHNSEN. 1976. Uptake of minerals, particularly metals, by epiphytic Hypnum cupressiforme. Oikos 27: 483-87.

Roberts, B. A. 1992. Ecology of serpentinized areas, Newfoundland, Canada, pp. 75-113. In: B. A. Roberts and J. Proctor, eds., The Ecology of Areas with Serpentinized Rocks: A World View. Kluwer Academic Publishers, Dordrecht, The Netherlands.

Roberts, B. A. AND J. Proctor, eds. 1992. The Ecology of Areas with Serpentinized Rocks: A World View. Kluwer Academic Publishers, Dordrecht, The Netherlands.

Samecka-Cymerman, A., A. J. Kempers, and B. Winter. 2002. Metal and macro-element concentration and effect of nutrient addition in terrestrial bryophytes growing on serpentine massifs in Lower Silesia, Poland. Environm. Geol. 43: 79-86. 
Sardans, J. and J. Peñuelas. 2005. Trace element accumulation in the moss Hypnum cupressiforme Hedw. and the trees Quercus ilex L. and Pinus halepensis Mill. in Catalonia. Chemosphere 60: 1293-1307.

SHaw, A. J. 1990. Genetic and environmental effects on morphology and asexual reproduction in the moss, Bryum bicolor. Bryologist 93: 1-6.

. 1991. Ecological genetics of serpentine tolerance in the moss, Funaria flavicans: Variation within and among haploid sib families. Amer. J. Bot. 78: 1487-1493.

- AND D. L. Albright. 1990. Potential for the evolution of heavy metal tolerance in Bryum argenteum, a moss. II. Generalized tolerances among diverse populations. Bryologist 93: 187-192.

—, J. Antonovics, And L. E. Anderson. 1987. Inter- and intraspecific variation of mosses in tolerance to copper and zinc. Evolution 41: $1312-1325$.

Shevock, J. R. 2003. Moss geography and floristics in California. Fremontia 31: $12-20$.

SigAL, L. L. 1975. Lichens and mosses of California serpentines. M.A. thesis, Univ. California, San Francisco, CA.

Sirois, L. 1984. Le plateau du Mont Albert: Étude phytoécologique. M.Sc. thesis, Univ. Laval, Québec, Canada.

— AND M. M. Grandtner. 1992. A phyto-ecological investigation of Mount Albert serpentine plateau, pp. 115-133. In: B. A. Roberts and J. Proctor, eds., The Ecology of Areas with Serpentinized Rocks: A World View. Kluwer Academic Publishers, Dordrecht, The Netherlands.

Stewart, D. B. And R. D. Tucker. 1998. Geology of Northern Penobscot Bay, Maine, with contributions to geochronology. U.S. Geological Survey, Miscellaneous Investigations Series Map, I-2551, U.S.G.S. New England Mapping Partnership Office, Northborough, MA. [scale 1:62500, 2 sheets]

TAKAKI, N. 1968. Serpentine moss flora of Mt. Hayachine. Kokuritsu Kagaku Haubutsukan senpo. Mem. Nat. Sci. Mus. (Tokyo) 1: 52-55.

TYLER, G. 1990. Bryophytes and heavy metals: A literature review. Bot. J. Linn. Soc. 104: 231-253.

VilHeLM, J. 1925. Les bryophytes serpentinomorphes des roches a serpentine des environs de Marianske Lazne, en Bohème. Publications Faculté Sciences Université Charles 33: 3-16.

Ward, N. I., R. R. Brooks, And E. Roberts. 1977. Heavy metals in some New Zealand Bryophytes. Bryologist 80: 304-311.

WhitTAker, R. H. 1954. The ecology of serpentine soils. IV. The vegetation response to serpentine soils. Ecology 35: 275-288.

Williamson, S. D. AND K. BALKwill. 2006. Factors determining levels of threat to serpentine endemics. S. African J. Bot. 72: 619-626.

Zechmeister, H. G. 2005. Die moosflora der serpentinarasen im Burgenland. Verh. Zool.-Bot. Ges. Österreich 142: 9-15. 